\title{
Studi In Silico Bioaktivitas Antikanker Senyawa Aktif Dalam Minyak Biji Buah Wali [Brucea javanica (L.) Merr]
}

\author{
Agus Dwi Ananto ${ }^{*}$, Handa Muliasari ${ }^{2}$, Candra Dwipayana Hamdin ${ }^{3}$ \\ 1,2,3 Program Studi Farmasi, Fakultas Kedokteran, Universitas Mataram, Mataram, Indonesia
}

\section{DOI : https://doi.org/10.29303/sjp.v1i2.13}

\section{Article Info}

Received : 2020-04-03

Revised : 2020-04-10

Accepted: 2020-04-10

\begin{abstract}
Insilico study of anticancer bioactivity in oil of "buah wali" [Brucea javanica (L.) Merr] has been successfully carried out. "Buah Wali" (Brucea javanica (L.) Merr) is known to treat various diseases such as diabetes, diarrhea, and malaria. In addition, "buah wali" seeds are supported to have antidiabetic, antioxidant, and anticancer activities. Stages of the study began by taking a sample of "buah wali" seeds, then extracted to get oil of "buah wali". While GC-MS analysis resulted Octadec-9-enoic acid (56.25\%), palmitic acid $(13.82 \%)$, stearic acid $(10.57 \%)$, and acids -9-octadecanoate $(5.91 \%)$ were found as the major components of the seed oil. Based on these compounds, docking molecullar was carried out to find anticancer bioactivity. The results obtained are compounds that have lower binding energy than the native ligands [Octadec-9-enoic acid (-72.4518), hexadecanoic acid (70.2136), octadecanooic (-72.2362).
\end{abstract}

Keywords: Docking molecular, Brucea javanica (L.) Merr, Anticancer

Citation: $\quad$ Ananto, AD., Muliasari, H., Hamdin, CD. (2020). Studi In Silico Bioaktivitas Antikanker Senyawa Aktif Dalam Minyak Biji Buah Wali [Brucea javanica (L.) Merr]. Sasambo Journal of Pharmacy, 1(2), 26-29. doi: https://doi.org/10.29303/sjp.v1i2.13

\section{Pendahuluan}

Brucea javanica (L.) Merr merupakan anggota famili Simaroubaceae. Tanaman ini di Pulau Lombok, NTB dikenal dengan nama "Buah Wali". Buah Wali ditemukan banyak tumbuh di wilayah Sesaot, Lombok Barat, NTB. Masyarakat setempat meyakini bahwa buah wali dapat mengobati berbagai penyakit seperti diabetes, diare, dan malaria. Berdasarkan penelitian yang pernah dilakukan, biji buah wali dilaporkan memiliki aktivitas antidiabetes, antioksidan, dan antikanker. Biji buah wali mengandung senyawa alkaloid, lignan, terpenoid, alkaloid glikosida, quassinoid glikosida, dan quassinoid. Quassinoid merupakan senyawa utama yang berhasil diisolasi dari famili Simaroubaceae dan diketahui memiliki aktivitas antikanker, antitumor, dan antidiabetes (Albat, et al., 2014).

Masyarakat di China telah banyak yang memanfaatkan buah wali sebagai salah satu bahan yang digunakan pada pengobatan tradisional dan dikenal memiliki karakter yang dingin dan berasa pahit sehingga memiliki berbagai aktivitas farmakologi. Buah wali dikenal sebagai tumbuhan yang berkhasiat antipiretik dan detoksifikasi. Selain itu, buah wali digunakan untuk mengobati kanker paru, prostat dan usus, serta berpotensi sebagai antimalaria, antiinflamasi, dan antivirus dengan toksisitas yang rendah (Chen, et al., 2013). Penelitian yang dilakukanpada bidang farmakologi menunjukkan adanya potensi mekanisme senyawa dalam buah wali sebagai antitumor dengan menginduksi terjadinya apoptosis dan menghambat proliferasi sel dengan cara mereduksi ekspresi gen Bcl-2 (Lou. et al., 2010).

Penelitian lain juga pernah dilakukan dalam rangka mengkaji tentang aktivitas antikanker minyak biji buah wali. Wu et al., (2017) menyatakan beberapa senyawa asam lemak dalam minyak biji buah wali seperti asam oleat, linoleat, palmitat dan stearat 
menghasilkan berbagai aktivitas biologis dan farmakologi dan dapat digunakan untuk mengobati berbagai jenis kanker seperti kanker paru, usus, dan hati. Mekanisme kerja senyawa tersebut sebagai antikanker adalah dengan menghambat pertumbuhan sel tumor dengan jalan menghambat sintesis DNA, menekan resistensi tumor terhadap obat, dan menghancurkan membrane sel tumor. Penelitian lain oleh Pan et al., (2018) menyatakan bahwa minyak biji buah wali dapat meningkatkan radiosensitifitas kanker esophagus dengan menghambat faktor penginduksi hipoksia 1a secara in vitro dan in vivo.

Korelasi antara struktur-aktivitas atau struktursifat terhadap data percobaan yang telah diperoleh dari penelitian sebelumnya merupakan tahapan yang bisa kita manfaatkan didalam mempelajari atau menentukan suatu senyawa yang berkhasiat. Salah satu bidang ilmu yang sangat terbantu dari pemahaman dalam mempelajari korelasi tersebut adalah kimia medisinal dan farmakologi. Parameter fisikokimia ini dapat dinyatakan secara kualitatif dan kuantitatif. Jika aktivitas obat yang termasuk dalam satu seri dapat diukur dengan cara kerja serupa, maka hubungan kuantitatif struktur-aktivitas dapat pula dihitung. Eksperimen ini menggunakan pendekatan dan penalaran yang rasional, sehingga dapat menghemat tenaga, biaya dan waktu. Selain itu, pendekatan ini juga dapat mengurangi hewan uji yang digunakan dan dapat mengurangi cemaran terhadap lingkungan (Ananto, 2018)

Penelitian ini mencoba untuk menentukan bioaktivitas antikanker senyawa aktif dalam minyak biji buah wali [Brucea javanica (L.) Merr] melalui pendekatan in silico. Data GLOBOCAN, International Agency for Research on Cancer (IARC), dilaporkan bahwa pada tahun 2012 terdapat sekitar 14 juta kasus baru kanker dan 8,2 juta kematian akibat kanker. Kasus kanker yang menyebabkan kematian paling banyak berturut-turut adalah : kanker paru $(19,7 \%)$, kanker payudara $(12,9 \%)$, kanker hati $(9,5 \%)$, dan kanker perut $(8,9 \%)$. Setiap tahunnya angka penderita kanker diperkirakan akan meningkat dan mencapai 23,6 juta kasus baru per tahun pada tahun 2030 (Kemenkes RI, 2016).

\section{Metode}

\section{Pengumpulan dan Pengolahan Sampel}

Sampel buah wali yang sudah tua dan matang dikoleksi di daerah hutan Sesaot, Kabupaten Lombok Barat Nusa Tenggara Barat. Sampel kemuadian dipisahkan dari kulit buah kemudian dikeringanginkan. Biji buah wali selanjutnya ditumbuk sampai menjadi serbuk simplisia.

\section{Isolasi dan identifikasi minyak biji buah wali}

Minyak biji buah wali diekstraksi dengan metode Sohxletasi menggunakan pelarut n-heksana. Serbuk simplisia biji buah wali dimasukkan ke dalam selongsong berupa kertas saring yang terikat dengan kuat. Besar pembuatan selongsong menyesuaikan dengan bentuk tabung Sohxlet. Selanjutnya proses ekstraksi dilakukan selama 2 jam pada suhu $70^{\circ} \mathrm{C}$. Setelah proses ekstraksi, pelarut n-heksan diuapkan menggunakan rotary evaporator. Setelah dilakukan isolasi, identifikasi kandungan senyawa dalam minyak buah wali dilakukan dengan menggunakan instrument GC-MS.

Studi in silico bioaktivitas senyawa aktif sebagai anti kanker

Pengujian secara in silico dilakukan melalui tahap preparasi protein dengan cara mengunduh data protein dari protein data bank (www.pdb.org), kemudian membukanya di aplikasi YASARA. Preparasi ligan dilakukan dengan cara mengekstrak file ligan dari pdb sebagai input file. Preparasi input file dengan menggunakan menggunakan aplikasi docking PLANTS. Tahapan berikutnya yaitu melakukan running docking kemudian ditunggu hingga semua proses selesai. Setelah proses running selesai maka akan diperoleh data hasil running. Berdasarkan data tersebut, maka bisa di interpretasikan apakah senyawa minyak biji buah wali memiliki bioaktivitas yang bisa digunakan sebagai antikanker.

\section{Hasil dan Pembahasan \\ Identifikasi Senyawa}

Hasil analisis kandungan senyawa dalam minyak biji buah wali [Brucea javanica (L) Merr] menggunakan instrumen GC-MS ditunjukkan pada Gambar 1. Minyak biji buah wali mengandung beberapa asam lemak dengan kelimpahan yang cukup besar seperti tertuang dalam Tabel 1. Kandungan utama dalam minyak biji buah wali berturut-turut adalah senyawa Octadec-9-enoic acid (56.25\%), asam palmitat $(13.82 \%)$, asam stearat $(10.57 \%)$, dan asam-9oktadekanoat (5.91\%). Penelitian Su et al. (2013) terhadap ekstrak petroleum eter biji buah wali juga mengindentifikasi adanya asam lemak dan ester dalam ekstrak tersebut. Berbagai senyawa asam lemak, ester, dan senyawa-senyawa lain yang terkandung dalam ekstrak biji buah wali menyebabkan ekstrak biji buah wali memiliki aktivitas antikanker.

Wu dkk. (2017) melaporkan komponen utama minyak biji buah Wali di China adalah asam lemak yang meliputi asam oleat, asam linoleat, asam linolenat, asam palmitat, dan asam stearate. Asam oleat dan linoleat adalah bahan aktif utama dalam minyak biji buah Wali yang memiliki berbagai aktivitas biologis dan farmakologis, dan biasanya digunakan untuk 
mengobati berbagai kanker, seperti sebagai kanker paru-paru, gastrointestinal, dan hati.

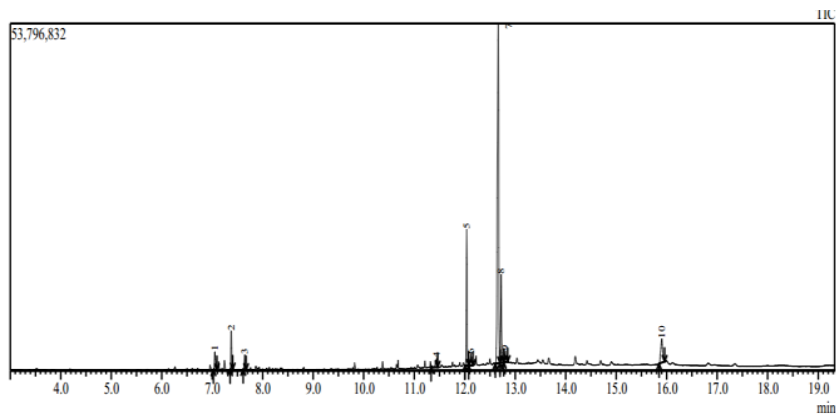

Gambar 1. Kromatogram minyak biji buah wali

Mekanisme penghambatan pertumbuhan tumor termasuk penghambatan sintesis DNA, penekanan resistensi multidrug tumor, dan penghancuran sel tumor sistem membran.

Tabel 1. Senyawa Utama dalam Minyak Biji Buah Wali Berdasarkan Hasil Analisis dengan GCMS

\begin{tabular}{|c|c|c|}
\hline $\begin{array}{c}\text { No } \\
\text { puncak }\end{array}$ & $\underset{(\%)}{\text { Kelimpahan }}$ & Senyawa \\
\hline 7 & 56.25 & Octadec-9-enoic acid \\
\hline 5 & 13.82 & $\begin{array}{l}\text { Asam heksadekanoat } \\
\text { (asam palmitat) }\end{array}$ \\
\hline 8 & 10.57 & $\begin{array}{c}\text { Asam oktadekanoat (asam } \\
\text { stearat) }\end{array}$ \\
\hline 10 & 5.91 & Asam-9-oktadekanoat \\
\hline
\end{tabular}

Berdasakan penelitian yang telah dilakukan oleh Chen dkk pada tahun 2013, Brucea javanica telah terbukti memiliki berbagai aktivitas farmakologis, dan yang dirasa paling luar biasa adalah aktivitas antitumornya. Ekstrak Brucea javanica telah menunjukkan efek antitumor yang kuat pada sel S180, dengan $24,6 \%$ penghambatan proliferasi sel pada dosis tinggi, sementara dosis menengah dan rendah dapat memperpanjang umur sekitar $20 \%$ pada tikus yang mengandung tumor (Tian GY, dkk, 2011)

Brucea javanica dapat membalik resistensi obat dalam sel tumor dengan mengubah P-glikoprotein pada membran sel. Misalnya, ketika sel-sel kanker ovarium yang resistan terhadap obat terpapar pada emulsi berminyak yang mengandung Brucea javanica, terjadi penurunan dramatis dalam jumlah sel yang resistan terhadap obat. Brucea javanica juga dapat menghambat aktivitas topoisomerase II, sehingga mempengaruhi sintesis DNA yang menyebabkan penangkapan siklus sel dan apoptosis, misalnya, penangkapan siklus sel G0 / G1 diinduksi oleh minyak Brucea javanica dalam sel hepatoma (Tian CT dkk,
2010). Penghentian siklus sel dan penghambatan sintesis DNA setelah pengobatan minyak Brucea javanica terlihat pada garis sel karsinoma lambung manusia SGC-7901 yang menunjukkan apoptosis (Sun B dkk, 2001). Sementara itu, sebuah penelitian barubaru ini juga memberikan bukti kuat bahwa minyak Brucea javanica dapat menginduksi apoptosis dari sel melalui aktivasi caspase-8 dan modulasi protein terkait apoptosis dalam garis sel leukemia myeloid manusia (Zhang, H dkk 2011).

\section{Penapisan senyawa secara insilico}

Penapisan virtual atau docking molecullar pada penelitian ini dilakukan dengan menggunakan aplikasi PLANT (Protein-Ligand Ant-System). Tahapan pertama yang peneliti lakukan adalah melakukan preparasi protein dan ref ligan. Protein yang digunakan untuk pendekatan penapisan ini yaitu protein dengan kode 1HD2 pada Protein Data Bank (PDB). Protein disini digunakan sebagai reseptor terhadap ref ligan.

Preparasi dilakukan dengan menggunakan aplikasi Marvin Sketch, struktur protein diambil dari PDB (www.rscb.org). Tahap persiapan protein dilakukan menggunakan aplikasi YASARA. Proses penapisan molekul menggunakan aplikasi PLANTS (Protein-Ligand Ant System). Setelah dilakukan preparasi, kemudian dilakukan validasi metode docking. Validasi metoda pada prinsipnya untuk mengetahui apakah PDB yang kita gunakan memenuhi persyaratan digunakan dalam molecular docking selanjutnya (Purnomo, 2013). Salah satu parameter sederhana yang digunakan dalam validasi metoda adalah Root Mean Square Deviation (RMSD). RMSD heavy atoms senyawa hasil docking dengan referensinya sebesar 1.0811 angstrom. Sebuah protokol diterima bila RMSD heavy atoms hasil docking dibandingkan dengan referensinya kurang dari 2.0 angstrom. Sehingga protokol yang dikembangkan untuk penelitian ini diterima dan dapat dikembangkan lebih lanjut untuk skrining virtual dalam usaha penemuan senyawa baru antikanker.

Nilai binding energy yang diperoleh pada tahap molecular docking komponen mayor minyak biji buah wali terhadap reseptor 1HD2 ditunjukkan pada tabel 2 .

Tabel 2. Analisa hasil docking

\begin{tabular}{ccc}
\hline No & Ligand & $\begin{array}{c}\text { Nilai binding } \\
\text { energy }\end{array}$ \\
\hline 1 & Ligand Native & -57.2906 \\
2 & Octadec-9-enoic acid & -72.4518 \\
3 & Asam heksadekanoat (asam & -70.2136 \\
4 & $\begin{array}{c}\text { palmitat) } \\
\text { Asam oktadekanoat (asam } \\
\text { stearat) }\end{array}$ & -72.2362 \\
5 & Benzene, 1-ethyl-3-methyl & -49.6322 \\
\hline
\end{tabular}


Berdasarkan Tabel 2 terlihat bahwa nilai binding energy senyawa 2 sampai senyawa 4 lebih rendah jika dibandingkan dengan ligan nativenya, hanya senyawa minor benzene, 1-ethyl-3-methyl yang memiliki nilai binding energy yang lebih besar. Hal ini bermakna bahwa keempat senyawa yang terdapat pada minyak biji buah wali terbukti memiliki potensi sebagai antikanker.

\section{Kesimpulan}

Berdasarkan hasil penelitian yang telah diperoleh, maka peneliti dapat menyimpulkan bahwa hasil analisis kandungan senyawa dalam minyak biji buah wali [Brucea javanica (L) Merr] menggunakan instrumen GC-MS terdapak komponen mayor senyawa seperti senyawa Octadec-9-enoic acid (56.25\%), asam palmitat $(13.82 \%)$, asam stearat $(10.57 \%)$, dan asam-9oktadekanoat (5.91\%). Senyawa utama tersebut kemudian diuji secara insilico terhadap protein target 1HD2 ternyata senyawa Octadec-9-enoic acid, senyawa asam heksadekanoat maupun senyawa asam oktadekanoat memiliki binding energy yang jauh lebih rendah disbanding ligan nativenya. Sehingga peneliti dapat menyatakan berdasarkan hasil studi in silico bahwa senyawa utama dalam minyak biji buah wali memiliki potensi sebagai antikanker.

\section{Daftar Pustaka}

Ananto, A.D 2018. Desain Senyawa Turunan Meisoindigo Baru Sebagai Anti Kanker Payudara. Penelitian PS. Farmasi Unram, Mataram

Albat, A., J. Mohamad., K. Awang., J.A. Shilpi., A. Arya. 2014. Evaluation of Antidiabetic and Antioxidant Properties of Brucea javanica Seed. Hindawi Publishing Corporation, The Scientific World Journal, volume 2014, http://dx.doi.org/10.1155/2014/786130.

Chen, M., R. Chen, S. Wang, W. Tan, Y. Hu, X. Peng, Y. Wang. 2013. Chemical components, pharmacological properties, and nanoparticulate delivery systems of Brucea javanica. International journal of nanomedicine. 2013:8, 85-92.

Kemenkes RI. 2016. Infodatin Pusat Data dan Informasi Kementerian Kesehatan RI Kanker Payudara. Jakarta : Kementerian Kesehatan RI.

Lou GG, Yao HP, Xie LP. 2010. Brucea javanica oil induces apoptosis in T24 bladder cancer cells via upregulation of caspase-3, caspase- 9 , and inhibition of NF-kappaB and COX-2 expressions. Am J Chin Med. Vol 38(3):613624.

Pan, P., B. Yang, X. Lin Ge. 2018. Brucea javanica seed oil enhances the radiosensitivity of esophageal cancer by inhibiting hypoxia-inducible factor $1 a$, in vitro and in vivo. Oncology letters. Vol 15: 3870-3875. DOI: 10.3892/ol.2018.7779.

Purnomo Hari, 2013. Kimia Komputasi Untuk Farmasi dan Ilmu Terkait. Pustaka Pelajar. Yogyakarta

Su, Z., H. Huang, J. Li, Y. Zhu, R. Huang, S.X. Qiu, 2013, Chemical Composition and Cytotoxic Activities of Petroleum Ether Fruit Extract of Fruits of Brucea javanica (Simarubaceae). Tropical Journal of Pharmaceutical Research October 2013; 12 (5): 735-742. ISSN: 1596-5996 (print);

1596-9827. http://dx.doi.org/10.4314/tjpr.v12i5.11

Sun B, Wu YN, Wang SN, Qiao MM, Zhang YP. Preliminary studies on anti-proliferative effect of Brucea javanica on the human gastric cancer cell SGC-7901. Shanghai Med J. 2001;24(8):481483

Tian GY, Xie RH. Experimental study on the anticancer effect of extract of Brucea javanica on mice of S180. Anti-tumor Pharmacy. 2011;1(3):220222.

Tian CT, Han LY. Inhibition of Brucea javanica oil emulsion on the proliferation of human liver cancer cell SMMC-7721 cells in vitro. Modern Oncology. 2010;18(4):654-655.

Wu, Z., L. Li, N. Li, T. Zhang, Y. Pu, X. Zhang, Y. Zhang and B. Wang. 2017. Optimization of Ultrasonic-assisted Extraction of Fatty Acids in Seeds of Brucea Javanica (L.) Merr. from Different Sources and Simultaneous Analysis Using High-Performance Liquid Chromatography with Charged Aerosol Detection. Molecules. Vol 22, 931, doi: 10.3390/molecules22060931.

Zhang H, Yang JY, Zhou F, et al. Seed oil of Brucea javanica induces apoptotic death of acute myeloid leukemia cells via both the death receptors and the mitochondrial-related pathways. Evid Based Complement Alternat Med. 2011:965016. 